\title{
QUANTIFICATION AND REMOVAL OF TRICHLORO- METHANE IN CHLORINATED WATER USING COCONUT SHELL ACTIVATED CARBON
}

\author{
A. A. Okoya*, O. E. Akinola, O. S. Adegbaju, A. B. Akinyele And O. S. Amuda \\ (A. A. O., O. E. A., O. S. A. \& A. B. A.: Institute of Ecology and Environmental \\ Studies, Obafemi Awolowo University, Ile-Ife, Nigeria; O. S. A.: Ladoke Akintola \\ University of Technology, Ogbomoso, Nigeria). \\ *Corresponding author's email: ronkeokoya@yahoo.com
}

\begin{abstract}
Commercially, available activated carbon (CAC) and coconut shell activated carbon (CSAC) were used in the adsorption of Trichloromethane (TCM) from disinfected water using the optimum conditions (concentration, dosage, $\mathrm{pH}$ and time) obtained. Concentrations of TCM were determined using GC-MS. Physicochemical parameters of CSAC were investigated. The CSAC gave percentage carbon yield $(86.72 \pm 1.41)$, surface area $1200 \mathrm{~m}^{2} / \mathrm{g}$ and CHNS/O Elemental Analyzer gave elemental Carbon of $60.08 \%$ as the highest of the elements in the char. A pore structure dispersed on the CSAC surface was observed. Best conditions for CSAC were: $1.4 \times 10^{4} \mu \mathrm{g} / 1 \mathrm{TCM}, 5.0 \mathrm{pH}, 0.8 \mathrm{~g}$ absorbent within 30 minutes. The data fitted Freundlich than Langmuir model ( $\mathrm{R}^{2}$ of 0.9977 and 0.9232 , respectively). Percentage removal of TCM for CAC and CSAC was $98.3 \pm 1.55$ and $96.7 \pm 1.27$, respectively for the water sample. Results indicated that CSAC was efficient for removal of TCM present in water and could be used as alternative for $\mathrm{CAC}$ in water treatment.
\end{abstract}

Keywords: Trichloromethane, coconut shell, activated carbon, removal efficiency, adsorbent.

\section{Introduction}

Increased consumption of coconut water and green coconut fruit pulp has increased the generation of coconut shells (Ayrilmis et al., 2011), which in some regions tends to become waste, generating negative social, economic and environmental impacts (Biggs et al., 2015). Coconut shell accounts for around $85 \%$ of the weight of the fruit (Ayrilmis et al., 2011) and has an assumed composition of $33.30 \%$ lignin, $30.58 \%$ cellulose, $26.70 \%$ hemicellulose, $8.86 \%$ water and $0.56 \%$ ash (Arena et al., 2016). The wastes of coconut residues are widely generated everywhere in the form of shells, husks and coir, which are obtained from the coconut milk and oil processing industries.
As biomass, they have the potential to be utilised as a source of carbon, or a fuel which can serve as an alternative energy source for different applications (Ahmad et al., 2020). Research has shown that there is potential for the use of coconut shells, in the form of fiber or powder, for the production of biosorbents for adsorption (Staron et al., 2017). Although, there are so many applications for the use of coconut shell, its manufacturing potential is not appreciated in many countries (Araujo et al., 2015). It is estimated that $1.5 \mathrm{~kg}$ of shell is lost from each coconut consumed in a country, which indicates a quantity of up to three million tons of unused green coconut per year (da Silva, 2014). However, the amount of 
green coconut shells that are thrown away at the place of consumption is unknown, which makes it difficult to manage the amount of residue produced (dos Santos et al., 2019).

The disposal of coconut shell is not quantifiable, and generally occurs in inappropriate environments such as beaches and vacant plots (Corradini et al., 2009), and it is therefore associated with the pollution of public spaces. As coconut shells can take up to ten years to degrade in the environment, causing unpleasantness in the urban environment, as well as becoming foci for mosquito breeding and disease transmission (Banerjee et al., 2013).

On the other hand, drinking water disinfection is essential for public health protection against waterborne infections. However, disinfection by-products (DBPs) are formed as an unintended consequence of water disinfection. DBPs form a complex mixture of hundreds of chemicals (Richardson et al., 2007; Hebert et $a l ., 2010)$ to which virtually the entire population in both under developed and developed countries are exposed through ingestion, inhalation, or dermal absorption when drinking or using municipal tap water and swimming in pools. Chlorine is the most widespread disinfectant used worldwide, and trihalomethanes (THMs) and haloacetic acids (HAAs) are the DBP classes formed at the highest concentrations after chlorination. Apart from disinfection methods, the characteristics of raw water (e.g., the content of natural organic matter) and the condition of the distribution system also determine the type and levels of DBPs found in municipal water (Charisiadis et al., 2015; Villanueva et al., 2015). Several DBPs have been shown to be genotoxic in vitro assays and carcinogenic in animal experiments (Richardson et al., 2007). The World Health Organization (WHO) and International Agency for Research on Cancer (IARC) therefore classify trichloromethane and other widespread DBPs as possible human carcinogens (Villanueva et al., 2015). A series of previous epidemiological studies has provided estimates of the relationship between DBPs exposure and the risk of cancer and adverse reproductive outcomes (Villanueva et al., 2015). Different meta-analyses and pooled analyses (King and Marrett, 1996; Villanueva et al., 2003; Villanueva et al., 2004; Costet et al., 2011) of studies in Europe and North America provide consistent evidence that long-term exposure to THMs, used as a surrogate of DBPs, is associated with an increased bladder cancer risk. Total THM concentrations representing the sum of chloroform, bromodichloromethane, dibromochloromethane, and bromoform are the only DBPs regulated in the European Union, with a maximum contaminant level of $100 \mu \mathrm{g} / \mathrm{L}$ (Council, 1998).

Thus, the development of agricultural wastes such as coconut shell into adsorbent to remove organic contaminants in water is a promising method. In essence, this not only helps to fully purify water, but also provides a long-term environmental protection. Hence this study optimized the conditions for the feasibility of coconut shell as an adsorbent for the removal of Trichloromethanes in water.

\section{Experimental}

All reagents used were of analytical grade and were obtained from SwWECh Lab, Institute of Ecology and Environmental Studies, Obafemi Awolowo University Ile-Ife, Nigeria. Burgoyne commercial activated carbon was obtained from Fortell Chemical Stores, Ile-Ife, Nigeria.

\section{Production of activated carbon}

The char of the raw material (coconut shell) was prepared using the methods of Susheela and Radha, 2015; Okoya et al., (2016). Pulverized coconut shell $(100 \mathrm{~g})$ was placed in a weighed crucible, and put into a furnace 
(EK 18/18 ESSEN (Germany)). The furnace temperature was set at $500^{\circ} \mathrm{C}$ and held at this temperature for 2 hours. The charred material was further cooled in an air-tight desiccator to room temperature. The cooled material was then weighed to determine the carbon yield of the material following the method of (Marsh \& Wynne-Jones, 1964).

\section{Activation of char}

The charred coconut shell was then soaked in $2 \% \mathrm{H}_{2} \mathrm{SO}_{4}(\mathrm{v} / \mathrm{v})$ and placed in an oven at a temperature of $110^{\circ} \mathrm{C}$ for 24 hours. The treated char was further washed with distilled water until the solution is no longer acidic. Then, the adsorbent was soaked in $2 \% \mathrm{NaHCO}_{3}(\mathrm{w} / \mathrm{v})$ to remove the residual acid. There, sample was finally dried in an oven at $110^{\circ} \mathrm{C}$, cooled to room temperature and stored in a desiccator until use according to (Amuda \& Ibrahim, 2006; Susheela \& Radha, 2015; Okoya et al., 2016).

\section{Characterization of activated char}

The elemental composition of the activated carbon was determined based on dry combustion method using a CHNS/O Elemental Analyzer. Scanning Electron Microscope (SEM) was used to determine the surface morphology of the activated carbon and structural chemical functional groups in the activated carbon was determined using the Fourier Transform Infrared Spectroscopy (SHIMADZU-FTIR-8400S).

\section{Physicochemical parameters of the coconut shell}

The activated coconut shell char was further characterized by examining its physicochemical parameters. From the physicochemical parameters, the $\mathrm{pH}$, moisture content, fixed carbon, Iodine number, volatile matter, and ash content were examined in relation to the origin of the raw material used.

\section{Batch adsorption experiment}

Batch adsorption experiment was carried out on the simulated Trichloromethane polluted water using coconut shell activated carbon as adsorbent and parameters including Trichloromethane concentration, $\mathrm{pH}$, adsorbent dosage and contact time were investigated. After each batch experiment, the Trichloromethane was extracted, concentrated and placed in GCMS vials for analysis.

\section{Physicochemical parameters of water samples} before adsorption

Water samples were collected at two sampling points (the raw water stage and after disinfection stage) in triplicate from Ondo State Water Corporation, Akure, Nigeria. Physicochemical parameters such as temperature, turbidity, total suspended solids, $\mathrm{pH}$, total dissolved solids, conductivity, alkalinity, total organic carbon, total hardness, chemical oxygen demand, chloride, nitrate, sulphate and nitrite of the water were determined following the standard procedure of Ademoroti (1996).

\section{Adsorption studies of disinfected water samples}

Adsorption studies were carried out on the disinfected water $(50 \mathrm{ml})$ using the optimum conditions of contact time (30 minutes), $\mathrm{pH}$ (5) and adsorbent dosage $(0.8 \mathrm{~g})$ as obtained from the batch adsorption of simulated polluted water. The initial concentration of the disinfected water was assessed by extraction and concentrated for Gas Chromatographic/Mass Spectrometric determination. Physicochemical parameters of the disinfected water were carried out after the adsorption process.

\section{Adsorption isotherm}

The data from the simulation experiments were subjected to both Langmuir and Freundlich adsorption isotherms. 


\section{Linearized Langmuir equation}

The linear form of the Langmuir (Salman et al., 2010; Langmuir, 1918) mode

$$
\frac{C_{e}}{q_{e}}=\frac{C_{e}}{q_{m}}+\frac{1}{k_{a} q_{m}}
$$

where:

$C_{e}(\mathrm{mg} / \mathrm{l})$ is the equilibrium concentration

$q_{e}(\mathrm{mg} / \mathrm{g})$ is the amount of Trichloromethane adsorbed at equilibrium

$q_{m(\mathrm{mg} / \mathrm{g})}$ is the adsorption for a complete monolayer

$K_{a}(\mathrm{~L} / \mathrm{mg})$ is the adsorption equilibrium constant

When $C_{e} / q_{e}$ is plotted against $C_{e}$ and the data regressed linearly, $q_{m}$ and $K_{a}$ constants are calculated from the slope and the intercept.

\section{Linearized Freundlich equation}

The linear form of the Freundlich (Ayranci \& Hoda, 2005; Freundlich, 1906) isotherm is:

$$
\operatorname{In} q_{e}=\operatorname{In} k_{f}+\frac{1}{n} \operatorname{In} C_{e}
$$

where:

$q_{e}(\mathrm{mg} / \mathrm{g})$ is the amount of Trichloromethane adsorbed at equilibrium

$K_{f}(\mathrm{mg} / \mathrm{g}(1 / \mathrm{mg}) 1 / \mathrm{n})$ is related to the adsorption capacity of activated carbon

$1 / \mathrm{n}$ is related to the surface heterogeneity. When $\ln \left(q_{e}\right)$ is plotted against $\ln C_{e}$ and the data is analysed by linear regression, $1 / \mathrm{n}$ and
$K_{f}$ constants can be determined from the slope and intercept, respectively (Ayranci \& Hoda, 2005; Freundlich, 1906).

\section{Results and discussion}

Characterization of the adsorbent Physicochemical Parameters of Coconut Shell and its Activated Carbon

The results of the physicochemical parameters of coconut shell char and its activated carbon are presented in Table 1. The result showed the $\mathrm{pH}$, ash content, yield, fixed carbon, volatile content and moisture content of the coconut shell char and total pore volume, Brunauer-Emmett-Teller (BET) surface area and iodine number of coconut shell activated carbon. The result revealed low ash content of $4.8 \pm 0.14 \%$ which is recognised with coconut shell. Low ash content explains why the shell can withstand a high temperature process (Girgis \& El- Hendawy, 2002). The result also showed a high yield of char $(86.72 \pm 1.41 \%)$ and carbon content of $49.29 \pm 0.67$ which shows that coconut shells are a good source for dense carbon as a result of its high lignin content (Yerima \& Grema, 2018). Coconut shell activated carbon showed a pore volume of $0.078 \mathrm{~cm}^{3} / \mathrm{g}$ and a high surface area of 1200 $\mathrm{m}^{2} / \mathrm{g}$. Higher adsorption is associated with high surface area and pore volume (Girgis \& El- Hendawy, 2002). Also, high iodine number informed high adsorption capacity of an adsorbent which is evident in the iodine number of coconut shell activated carbon shown in Table 1. 
TABLE 1

Physicochemical Parameters of Coconut shell and its Activated Carbon

\begin{tabular}{lccc}
\hline Parameter & Unit & Coconut Shell Char & Coconut Shell Activated Carbon \\
\hline $\mathrm{pH}$ & - & $5.4 \pm 0.14$ & $\mathrm{NA}$ \\
Ash & $(\%)$ & $4.8 \pm 0.14$ & $\mathrm{NA}$ \\
Yield & $(\%)$ & $86.72 \pm 1.41$ & $\mathrm{NA}$ \\
Fixed carbon & $(\%)$ & $49.29 \pm 0.67$ & $\mathrm{NA}$ \\
Moisture Content & $(\%)$ & $5.6 \pm 0.42$ & $\mathrm{NA}$ \\
Volatile Content & $(\%)$ & $40.31 \pm 1.24$ & $\mathrm{NA}$ \\
Brunauer-Emmett-Teller & $\left(\mathrm{m}^{2} / \mathrm{g}\right)$ & $\mathrm{NA}$ & 1200 \\
(BET) Surface area & $\left(\mathrm{cm}^{3} / \mathrm{g}\right)$ & $\mathrm{NA}$ & 0.078 \\
Total pore volume & $\left(\mathrm{mg}^{\mathrm{g}}\right)$ & $\mathrm{NA}$ & $986 \pm 11.3$ \\
Iodine number & & & \\
\hline
\end{tabular}

$\mathrm{NA}=$ Not Applicable

\section{Elemental Composition of the Char}

Fig. 1 shows the elemental composition of coconut shell char. The percentage of carbon content (60.08) in the char is the highest of all the elements detected. This is due to the pyrolytic effect of the char at a high temperature whereby almost all of the organic substances in the char must have reduced into liquid and gaseous substances, hereby, producing a material of high carbon purity. The quantity of the hydrogen is depleted because of the ruptured organic molecular chains according to Azam et al., 2009

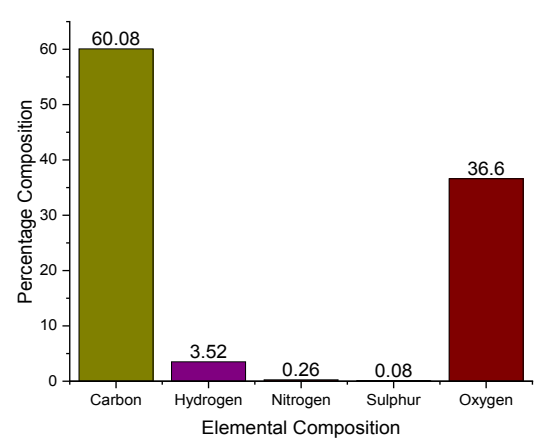

Fig. 1: CHNS/O Elemental composition of coconut shell.
Functional Groups of Coconut Shell Activated

\section{Carbon}

Fig. 2 shows the functional groups present in the coconut shell activated carbon. The FTIR spectroscopy was used to characterize the structure and functional groups of coconut shell activated carbon. The functional groups present are the hydroxyl group at bandwidth of $3421.83 \mathrm{~cm}^{-1}$, alkanes at bandwidth of 2949.26 $\mathrm{cm}^{-1}$, a peak at $1685.84 \mathrm{~cm}^{-1}$ corresponds to carbonyls in the $\mathrm{C}=\mathrm{O}$ stretching vibration such as carboxylic, aldehydes, ketones, and lactones group (Budinova et al., 2006). According to (Foo \& Hammed, 2009) band at 1589-1508 $\mathrm{cm}^{-1}$ denotes the $\mathrm{C}=\mathrm{C}$ stretching vibration in aromatic rings, this band is due to the tars produced during depolymerization of cellulose followed by dehydration and condensation which led to the formation of more aromatic and reactive products with some cross linking. Other bands include the benzene, metal-halogen, esters and ethers groups. 


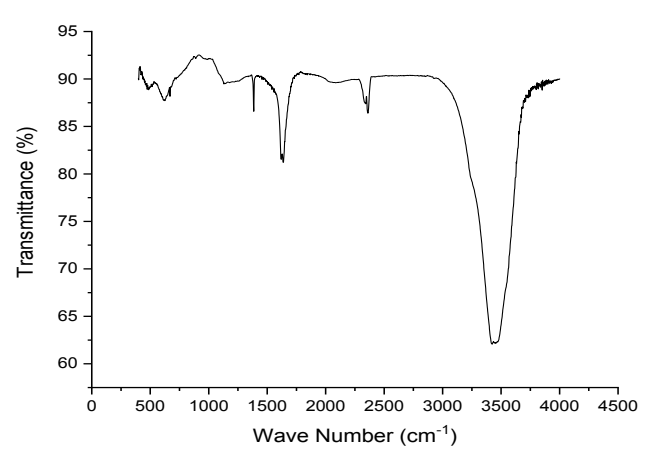

Fig. 2: FTIR of coconut shell Activated Carbon.

Surface Morphology of Coconut Shell Activated Carbon

Fig. 3 (a) explains the surface morphology of the activated carbon which explains the mass of particle and the surface morphology of the adsorbent. The adsorbent surface shows a shallow hollow tube with perfect pore sizes which enables access into the internal pores, the pores has clear opening which allows for ease of entry into the internal pores. The surface of the coconut shell activated carbon possesses a smooth surface with small pores distributed over it (Azam et al., 2009) while Fig. 3 (b) shows the surface morphology of the adsorbent after adsorption. It was observed that the pore structure which appeared hollow were already reduced, this maybe as a result of the adsorbate molecules picked up to fill the pore.

(a)

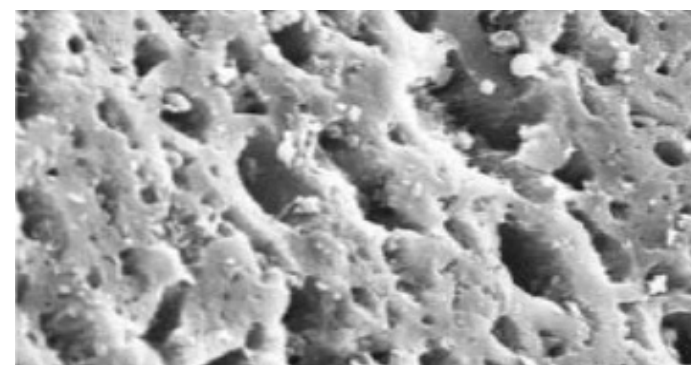

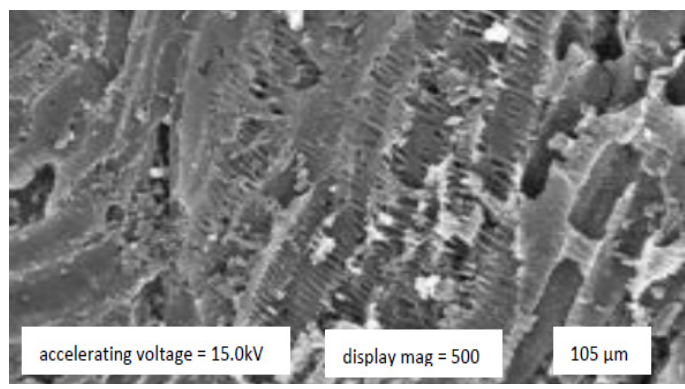

Fig. 3a \& b: SEM of coconut shell activated carbon (a) before adsorption (b) after adsorption.

\section{Effect of Initial Concentration on Adsorption of Trichloromethane}

The results obtained from the investigation of the adsorption of Trichloromethane using coconut shell activated carbon with varied initial concentration are presented below in Fig. 4. The removal efficiency of Trichloromethane increased from $79.9 \%$ to $99.1 \%$ as the initial concentration decreased from $1.4 \times 10^{6} \mu \mathrm{g} / 1$ to $1.4 \times 10^{4} \mu \mathrm{g} / \mathrm{l}$. This implies that the activated carbon will remove the slightest contamination with TCM. The highest adsorption efficiency was recorded at Trichloromethane concentration of $1.4 \times 10^{4} \mu \mathrm{g} / \mathrm{l}$ while the lowest adsorption efficiency was recorded at Trichloromethane concentration of $1.4 \times 10^{6} \mu \mathrm{g} / \mathrm{l}$. It has been observed that a second mechanism of intra-particle diffusion will be activated once the surface of the adsorbent was almost clogged with adsorbates, this second mechanism will induce the adsorption more but in a very slow and time consuming process as the reaction is carried out inside the carbon matrix (Malik et al., 2003). 


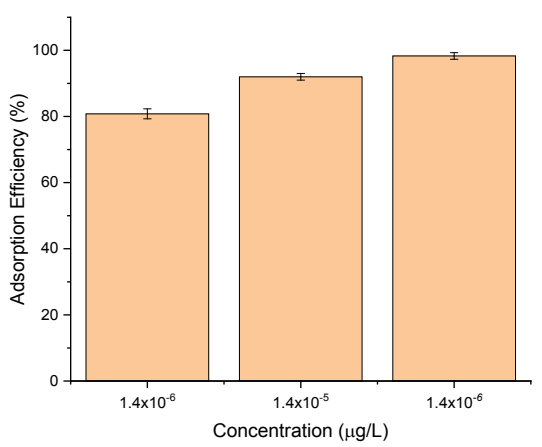

Fig. 4: Effect of Initial Concentration on Adsorption of Trichloromethane.

Effect of Adsorbent Dosage on Adsorption of Trichloromethane

The result of different adsorbent dosage for the adsorption of Trichloromethane by coconut shell activated carbon is presented in Fig. 5. Adsorbent dose of $0.8 \mathrm{~g}$ had the highest removal efficiency and percentage yields. The percentage removal of Trichloromethane increased from $76 \%$ to $98.7 \%$ along the adsorbent dose increase from $0.2 \mathrm{~g}$ to $0.8 \mathrm{~g}$. As the adsorbent dose increases, free sorption surface and adsorption sites will also be increased and therefore adsorbing more Trichloromethane (Chen et al., 2016; Ahmaruzzaman, 2008).

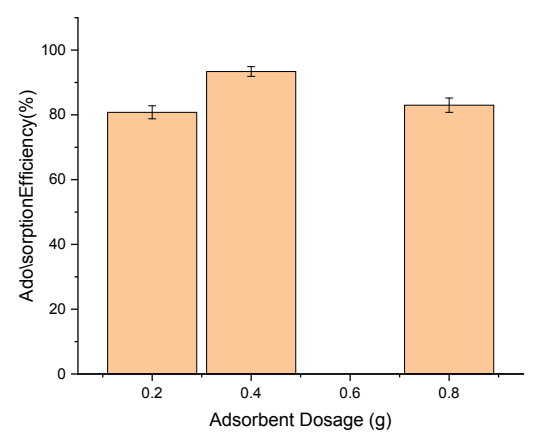

Fig. 5: Effect of Adsorbent Dosage on Adsorption of Trichloromethane

\section{Effect of pH on Adsorption of}

\section{Trichloromethane}

The results of the investigation of the adsorption of Trichloromethane on coconut shell activated carbon with varied $\mathrm{pH}$ are presented in Fig. 6. The effect of the $\mathrm{pH}$ on adsorption of Trichloromethane were determined using solution with different $\mathrm{pH}$ values of 5,7 and 9. The removal efficiency of Trichloromethane decreased from $81.7 \%$ to $79.9 \%$ as the $\mathrm{pH}$ increased from 5 to 9 . This study shows that at low $\mathrm{pH}$ ( $\mathrm{pH}$ of 5), adsorption efficiency was highest with a percentage removal of $81.7 \%$ due to the hydroxyl bonds on the adsorbent (Yang \& Lua, 2003; Bansal \& Goyal, 2005). Also, at $\mathrm{pH} 7$, the rate of Trichloromethane removal was $80.8 \%$. However, the adsorption of Trichloromethane decreases as the $\mathrm{pH}$ exceeds 7. This is due to the fact that more oxygen-containing groups on the coconut shell activated carbon's surface are ionized at higher $\mathrm{pH}$ values and thus they adsorb more water (Peng et al., 2003). The formation of water cluster on these groups blocks the access of Trichloromethane molecules to adsorption sites and results in less adsorption of Trichloromethane.

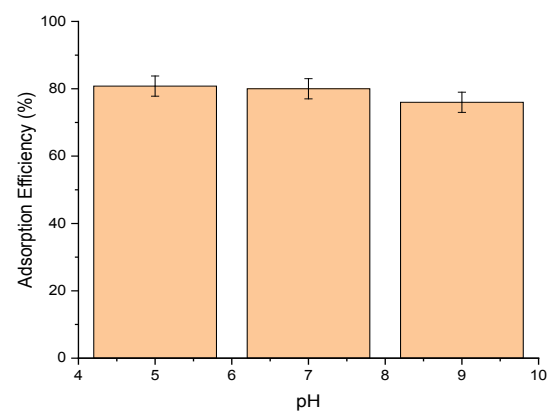

Fig. 6: Effect of $\mathrm{pH}$ on Adsorption of Trichloromethane. 
Effect of Contact time on Adsorption of Trichloromethane

Contact time plays a significant role in the efficient adsorption of contaminants. The results of the adsorption of Trichloromethane on coconut shell activated carbon with varied contact time are presented in Fig. 7.

The adsorption of Trichloromethane onto coconut shell activated carbon at the best initial concentrations $\left(1.4 \times 10^{4} \mu \mathrm{g} / \mathrm{l}\right)$ was studied as a function of contact time to determine the equilibrium time. Fig. 7 illustrates the adsorption study of Trichloromethane onto coconut shell activated carbon at various contact time. The adsorption rate was rapid thereby increasing the amount of adsorbates adhered to the carbon surface majorly within the first 30 minutes of adsorption and then reached equilibrium. This might be because of the initial availability of large number of vacant sites for adsorption, later the adsorption limit tailed off because of the saturation of vacant sites. The dynamic increment in adsorption and consequently the attainment of equilibrium adsorption maybe due to limited mass transfer of Trichloromethane molecules from the bulk solution to the outside surface of the adsorbent (Wang and Wu, 2006; Onundi et al., 2011).

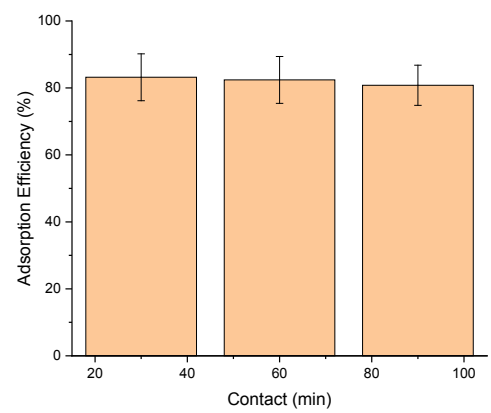

Fig. 7: Effect of Contact time on Adsorption of Trichloromethane.
Adsorption Studies on Influent Raw and Disinfected Water

The concentration of Trichloromethane as determined for the water samples at the raw and disinfected stage is shown in Table 2. Table 2 also showed physicochemical parameter of water samples at the raw and disinfected stage as well as physicochemical parameter after adsorption of the water samples at the disinfected stage. The results showed that parameters such as temperature, $\mathrm{pH}$ and turbidity increased after adsorption while conductivity, total dissolved solids, total suspended solids, alkalinity, total organic carbon, total hardness, COD, $\mathrm{NO}_{3}, \mathrm{Cl}^{-}, \mathrm{SO}_{4}^{2-}$, decreased after adsorption for treated water. The Trichloromethane values was found to be below detectable limits for the raw water samples and $167.3 \mu \mathrm{g} / \mathrm{l}$ for the disinfected water. The fact that Trichloromethane was not detected in the raw water was expected as disinfection has not taken place during this stage of drinking water treatment (Shaibu et al., 2015). However, the level of Trichloromethane in disinfected water is attributed to reaction between the disinfectant (Chlorine) and the dissolved organic matter as disinfection by-product precursors. 
TABLE 2

\begin{tabular}{|c|c|c|c|c|c|c|}
\hline $\mathbf{S} / \mathbf{N}$ & Parameters & Units & Raw Water & $\begin{array}{l}\text { Disinfected } \\
\text { Water Before } \\
\text { Adsorption }\end{array}$ & $\begin{array}{l}\text { Disinfected } \\
\text { Water After } \\
\text { Adsorption }\end{array}$ & $\begin{array}{l}\text { WHO } \\
\text { Standards } \\
\text { Guideline } \\
\text { Values }\end{array}$ \\
\hline 1 & Temperature & ${ }^{\circ} \mathrm{C}$ & $25.95 \pm 0.07$ & $26.25 \pm 0.07$ & $26.65 \pm 0.21$ & $25-32$ \\
\hline 2 & $\mathrm{pH}$ & - & $6.30 \pm 0.00$ & $6.90 \pm 0.14$ & $7.1 \pm 0.14$ & 6.5 \\
\hline 3 & Conductivity & $\mu / \mathrm{cm}$ & $110.85 \pm 0.25$ & $303.5 \pm 12.02$ & $182.15 \pm 1.06$ & 2500 \\
\hline 4 & Turbidity & NTU & $8.58 \pm 0.12$ & $0.94 \pm 0.59$ & $1.95 \pm 0.21$ & 5 \\
\hline 5 & $\begin{array}{l}\text { Total Suspended } \\
\text { Solids }\end{array}$ & $\mathrm{mg} / \mathrm{l}$ & $2.73 \pm 0.28$ & $1.38 \pm 0.02$ & $0.44 \pm 0.02$ & 100 \\
\hline 6 & $\begin{array}{l}\text { Total Dissolved } \\
\text { Solids }\end{array}$ & $\mathrm{mg} / \mathrm{l}$ & $128.50 \pm 0.71$ & $144.5 \pm 0.71$ & $43.70 \pm 0.60$ & 500 \\
\hline 7 & Alkalinity & $\mathrm{mg} / \mathrm{l}$ & $65.67 \pm 0.94$ & $54.81 \pm 0.12$ & $31.26 \pm 1.61$ & 50 \\
\hline 8 & $\begin{array}{l}\text { Total Organic } \\
\text { Carbon }\end{array}$ & $\mathrm{mg} / \mathrm{l}$ & $6.70 \pm 1.15$ & $5.40 \pm 0.047$ & $1.81 \pm 0.13$ & 25 \\
\hline 9 & Total Hardness & $\begin{array}{l}\mathrm{mg} / 1 \\
\mathrm{CaCO}\end{array}$ & $66.84 \pm 9.90$ & $32.81 \pm 0.89$ & $10.13 \pm 0.049$ & \\
\hline 10 & COD & $\mathrm{mg} / \mathrm{l}$ & $18.84 \pm 0.09$ & $2.24 \pm 0.014$ & $0.68 \pm 0.014$ & 250 \\
\hline 11 & $\mathrm{NO}_{3}^{-}$ & $\mathrm{mg} / \mathrm{l}$ & $1.27 \pm 0.03$ & $0.87 \pm 0.02$ & $0.21 \pm 0.028$ & 10 \\
\hline 12 & $\mathrm{NO}_{2}^{-}$ & $\mathrm{mg} / \mathrm{l}$ & $0.015 \pm 0.007$ & $0.00 \pm 0.00$ & $0.00 \pm 0.00$ & 0 \\
\hline 13 & $\mathrm{Cl}^{-2}$ & $\mathrm{mg} / 1$ & $19.00 \pm 2.60$ & $19.50 \pm 0.04$ & $10.1 \pm 0.028$ & $250-1000$ \\
\hline 14 & $\mathrm{SO}_{4}^{2-}$ & $\mathrm{mg} / 1$ & $4.64 \pm 0.02$ & $0.5 \pm 0.71$ & $0.15 \pm 0.07$ & 400 \\
\hline 15 & $\begin{array}{l}\text { Trichloromethane } \\
\text { (coconut shell acti- } \\
\text { vated carbon using } \\
\text { GC-MS) }\end{array}$ & $\mu \mathrm{g} / 1$ & $\begin{array}{l}\text { Below Detec- } \\
\text { tion Limit }\end{array}$ & $167.3 \pm 0.00$ & $5.52 \pm 2.12$ & 100 \\
\hline 16 & $\begin{array}{l}\text { Trichloromethane } \\
\text { (commercial acti- } \\
\text { vated carbon using } \\
\text { GC-MS) }\end{array}$ & $\mu \mathrm{g} / 1$ & & $167.3 \pm 0.00$ & $2.83 \pm 2.58$ & 100 \\
\hline
\end{tabular}

Adsorption experiment was conducted to investigate the Trichloromethane removal. The optimum parameters obtained during simulation experiment were utilised in the field adsorption study where Burgoyne commercial activated carbon which obtained from a chemical store was compared with coconut shell activated carbon. Table 3 compares the adsorption efficiency of coconut shell activated carbon with commercial activated carbon on disinfected water.
TABLE 3

Adsorption Efficiency of Coconut Shell Activated Carbon and Commercial Activated Carbon on Disinfected Water

\begin{tabular}{lll}
\hline Contaminant & Adsorbent & $\begin{array}{l}\text { Adsorption } \\
\text { Efficiency (\%) }\end{array}$ \\
\hline $\begin{array}{l}\text { Trichlorometh- } \\
\text { ane }\end{array}$ & $\begin{array}{l}\text { Coconut shell } \\
\text { activated } \\
\text { carbon }\end{array}$ & $96.7 \pm 1.27$ \\
& $\begin{array}{l}\text { Commercial } \\
\text { activated } \\
\text { carbon }\end{array}$ & $98.3 \pm 1.55$ \\
\hline
\end{tabular}

Confidence level $=0.05$

Significant value $=0.079$ 
This result indicates that among the two experimental carbons, the commercially available activated carbon slightly exceeded the coconut shell activated carbon in their adsorption performance, this could be due to the inhibition of small organics from penetrating into the micropores due to the greater number of polar compounds present on the mesopore and macropore surface of the acid activated coconut shell carbons (El-Demerdash et al., 2015). This agrees with Abdullah (2012) who reported that natural activated carbon removed about $84 \%$ of Trichloromethane. Moreover, the removal efficiency of the coconut shell activated carbon was found to be comparable to that of the commercially available activated carbon. This shows that the use coconut shell activated carbon for the removal of Trichloromethane in water is excellent as well as the commercially available activated carbon.

\section{Adsorption Isotherms}

The results of the sorption performance of Trichloromethane using coconut shell activated carbon were analysed using the Langmuir and Freundlich adsorption isotherms and were presented in Fig. 8 while Table 4 shows the coefficients of these isotherms (Langmuir and Freundlich). The results show that the adsorp- tion process is suitable with both Langmuir and Freundlich isotherms but fitted Freundlich better.

(a)

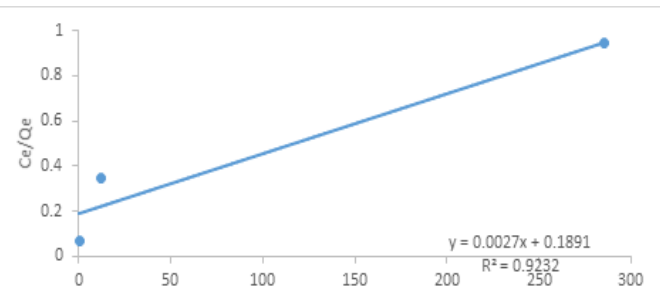

(b)

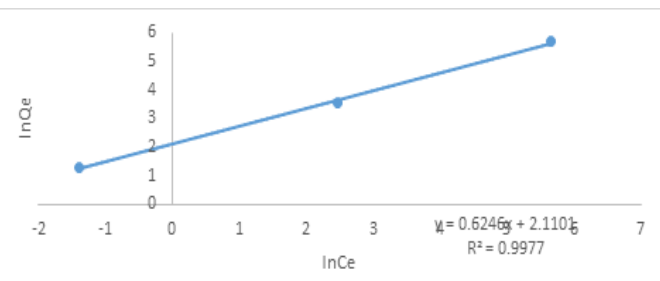

Fig. 8: (a) Langmuir adsorption isotherms for the adsorption of Trichloromethane using coconut shell activated carbon (b) Freundlich adsorption isotherms for the adsorption of Trichloromethane using coconut shell activated carbon.

TABLE 4

Langmuir and Freundlich constants for the adsorption of

Trichloromethane using coconut shell activated carbon

\begin{tabular}{lllllll}
\hline \multirow{2}{*}{ Adsorbent } & \multicolumn{4}{l}{ Langmuir constants } & \multicolumn{4}{l}{ Freundlich constants } \\
\cline { 2 - 6 } & $\mathrm{q}_{\mathrm{m}}(\mathrm{mg} / \mathrm{g})$ & $\mathrm{k}_{\mathrm{a}}(\mathrm{L} / \mathrm{mg})$ & $\mathrm{R}^{2}$ & $1 / \mathrm{n}$ & $\mathrm{k}_{\mathrm{f}}\left(\mathrm{mg} / \mathrm{g}(1 / \mathrm{mg})^{\mathrm{I/n}}\right.$ & $\mathrm{R}^{2}$ \\
\hline $\begin{array}{l}\text { Coconut shell } \\
\text { activated carbon }\end{array}$ & 370.3703 & 0.0143 & 0.9232 & 0.6246 & 8.2491 & 0.9977 \\
\hline
\end{tabular}

$\mathrm{R}^{2}=$ correlation coefficient

The correlation coefficient $\left(\mathrm{R}^{2}\right)$ of isotherm equation greater than 0.95 reveals the experimental isotherm data suitability. From Table 4, Freundlich isotherm equation showed cor- relation coefficient $\left(\mathrm{R}^{2}\right)$ value greater than 0.95 which makes the experimental data suitable for Freundlich isotherm. This result also explains the multilayer coverage formation of 
Trichloromethane molecule on the surface of the coconut shell activated carbon (Salman et $a l ., 2011$ ). The $\mathrm{k}_{\mathrm{f}}$ value determines the adsorbent adsorption capacity at equilibrium concentration in a solution (Katarzyna, 2009).

A higher $k_{f}$ value corresponds to a higher adsorption capacity and according to the $\mathrm{k}_{\mathrm{f}}$ values in Table 4 , the coconut shell activated carbon adsorption capacity for Trichloromethane studied is high. Correspondingly, substances with high molecular weight have more tendency to be adsorbed than compounds with low molecular weight (Katarzyna, 2009).

The slope $(1 / \mathrm{n})$ value in Freundlich's equation allows for assessing the adsorption intensity of a given substance from water phase of adsorbent (Katarzyna, 2009). The 1/n value is known as the heterogeneous factor which ranges from 0 to 1 (Ayranci, \& Hoda, 2005); the more heterogeneous the surface, the closer $1 / \mathrm{n}$ is to 0 (Al Duri, 1995). The slope $(1 / n)$ values for Trichloromethane in coconut shell activated carbon was $<1$ suggesting the adsorption isotherms to be nonlinear. A slope $<1$ shows that L-type isotherms, which are defined by a decrease in the adsorption at higher aqueous concentration of compounds, thus, sorption of Trichloromethane in coconut shell activated carbon was concentration dependent (Tan et al., 2008).

The Langmuir isotherm can also be explained by the correlation coefficient $\left(\mathrm{R}^{2}\right)$, the value of $\mathrm{R}^{2}$ denotes the isotherm type to be either unfavourable $\left(\mathrm{R}^{2}>1\right)$, linear $\left(\mathrm{R}^{2}=\right.$ $1)$, favourable $\left(0<\mathrm{R}^{2}<1\right)$, or irreversible $\left(\mathrm{R}^{2}\right.$ $=0$ ). The values of $R^{2}$ (Table 4 ) in this study are observed to be less than 1 , showing that the adsorption process is fit for coconut shell activated carbon (Hameed, et al., 2007; Tan et al., 2008).

\section{Conclusion}

The best adsorption conditions for Trichloromethane in this study are $1.4 \times 10^{4} \mu \mathrm{g} / 1$ concentration, contact time of 30 minutes, $\mathrm{pH}$ of 5 and adsorbent dosage of $0.8 \mathrm{~g}$. A conformation to the common adsorption isotherm models, Freundlich and Langmuir shows that coconut shell activated carbon is suitable for this adsorption. Coconut shell show well-defined pores with large surface area which provides abundant adsorption sites, therefore, improving the solute uptakes. Adsorption capacity of coconut shell activated carbon was very good and similar to commercial activated carbon. These findings are essential to enhance the quality of agricultural solid waste, particularly coconut shell as one of the most promising activated carbon precursors.

\section{Recommendation}

Water treatment plants should introduce use of adsorbents after disinfection stage in addition to the conventional treatment process. Activated carbon made from coconut shell should be used as low-cost high performance adsorbent in drinking water treatment for disinfection by-products removal. Commercial production of activated carbon from coconut shell could be lucrative for business investors which can also improve the economy of the country. More researches should be done on the use of natural adsorbents for treatment of drinking water.

\section{References}

Ademoroti, C. (1996) Standard methods for water and effluents analysis. Ibadan: Foludex Press Ltd 3, $29-118$.

Ahmad, R. K., Sulaiman, S. A., Yusuf, S. B., Dol, S. S., Umar, H. \& InAYat, M. (2020) The influence of pyrolysis process conditions on the quality of coconut shells charcoal. Platform: A Journal of Engineering 4 (1), 73 - 81. 
Ahmaruzzaman, M. D. (2008) Adsorption of phenolic compounds on low-cost adsorbents: a review. Advances in Colloid and Interface Science $143,48-67$.

Al Duri, B. (1995) Adsorption Modelling and Mass Transfer, Use of Adsorbents for the Removal of Pollutants from Wastewaters, CRC Press, Boca Raton.

Amuda, O. S. \& Ibrahim, A.o. (2006) Industrial wastewater treatment using natural material as adsorbent. African Journal of Biotechnology 5 (16), $1483-1487$.

Araujo, P., Felix Filho, L. F. \& Barbosa, J. J. (2015) Estudo das propriedades termofísicas da fibra de coco minimamente processada visando aplicação como isolante térmico. Revista Interdisciplinar de Pesquisa e Inovação 1 (1).

ARENA, N., LEE, J. \& CLIFT, R. (2016) Life cycle assessment of activated carbon production from coconut shells. Journal of Cleaner Production 125, $68-77$.

Ayranci, E. \& Hoda, N. (2005) Adsorption Kinetics and Isotherms of Pesticides onto Activated Carbon-Cloth. Chemosphere 60 (11), 1600 .

Ayrilmis, N., Jarusombuti, S., Fueangvivat, V., BauChongkol, P. \& White, R. H. (2011) Coir fiber reinforced polypropylene composite panel for automotive interior applications. Fibers and Polymers 12 (7), 919.

Azam T., Hameed, H. \& Abdul, L. (2009) Batch adsorption of phenol onto physiochemical-activated Coconut shell. Journal of Hazardous Materials 161, 1522 - 1529.

Banerjee, S., Aditya, G. And Saha, G. K. (2013) Household disposables as breeding habitats of dengue vectors: Linking wastes and public health. Waste management 33 (1), 233 - 239.

Bansal, R. P. \& Goyal, M. (2005) Activated Carbon Adsorption, CRC Press, Taylor \& Francis Group, 6000 Broken Sound Parkway NW, Suite 300 Boca Raton, FL, USA.
Biggs, E. M., Bruce, E., Boruff, B., Duncan, J. M., Horsley, J., Pauli, N., Mcneill, K., Neef, A., Van Ogtrop, F. \& Curnow, J. (2015) Sustainable development and the water-energy-food nexus: A perspective on livelihoods. Environmental Science \& Policy 54, 389 - 397.

Budinova, T., Ekinci, E., Yardim, F., Grimm, A., Buornbom, E., Minkova, V. \& Goranova, M. (2006) Characterization and application of activates carbon produced by $\mathrm{H}_{3} \mathrm{PO}_{4}$ and water vapour activation. Fuel Processing Technology 87, $899-905$.

Charisiadis, P., Andra, S. S., Makris, K. C., Christophi, C. A., Skarlatos, D., Vamvakousis, V., Kargaki, S. \& Stephanou, E. G. (2015) Spatial and seasonal variability of tap water disinfection by-products within distribution pipe networks. Science of the Total Environment 506, $26-35$.

Chen, S., Zhang, J., Zhang, C., Yue, Q., Li, Y. \& Li, C. (2016) Equilibrium and kinetic studies of methyl orange and methyl violet adsorption on activated carbon derived from Phramites australis. Desalination 252, 149 - 156.

Corradini, E., Rosa, M. D. F., Macedo, B. P. D., Paladin, P. D. \& Mattoso, L. H. C. (2009) Composição química, propriedades mecânicas e térmicas da fibra de frutos de cultivares de coco verde. Revista Brasileira de Fruticultura 31 (3), $837-846$.

Costet, N., Villanueva, C., JaAkkola, J., Kogevinas, M., Cantor, K., King, W., Lynch, C., NieuWENHUIJSEn, M. \& CoRdier, S. (2011) Water disinfection by-products and bladder cancer: Is there a european specificity? A pooled and meta-analysis of european case-control studies. Occupational and environmental medicine 68 (5), 379 - 385 .

COUNCIL, E. (1998) Council directive 98/83 about water quality intended for human consumption. Official Journal of the European Communities L. 330, 32 - 54.

Da Silva, A. C. (2014) Reaproveitamento da casca de coco verde. Revista Monografias Ambientais 13 (5), 4077 - 4086. 
Dos Santos, D. E., Martinez, F. C. C. \& Juiz, P. J. L. (2019) A fibra de coco como matéria-prima para o desenvolvimento de produtos: Uma prospecção tecnológica em bancos de patentes. Cadernos de Prospecção 12 (1), 153.

El-Demerdash, F. M., Abdullah, A. M. \& Ibrahim, D. A. (2015) Removal of Trihalomethanes Using Activated Carbon Prepared from Agricultural Solid Wastes. Hydrology Current Research 6, 193.

Foo, K.Y. \& Hameed, B. H. (2009) Utilization of biodiesel waste as a renewable resource for activated carbon: application to environmental problems. Renewable Sustainable Energy Reviews 13, 2495 - 2504.

FreUndLICH, H. (1906) U”ber die Adsorption in Lo" sungen (Adsorption in Solution). Zeitschriftfur Physikalische Chemie 57 (1), 384.

Girgis, B. S. \& El-Hendawy, A. A. (2002) Porosity development in activated carbonsobtained from date pits under chemical activation with phosphoric acid. Microporous and Mesoporous Materials 52, $105-117$.

Hameed, B., Din, A. M., \& Ahmad, A. (2007) Adsorption of methylene blue onto bamboo-based activated carbon: kinetics and equilibrum studies. Journal of hazardous materials 141 (3), $819-825$.

Hebert, A., Forestier, D., Lenes, D., Benanou, D., Jacob, S., Arfi, C., Lambolez, L. \& Levi, Y. (2010) Innovative method for prioritizing emerging disinfection by-products (dbps) in drinking water on the basis of their potential impact on public health. Water research 44 (10), $3147-3165$.

Katarzyna, I. (2009) Selection of Sorbent for Removing Pesticides during Water Treatment. Journal of Hazardous Materials 169 (1 - 3), 953.

KInG, W. D. \& Marrett, L. D. (1996) Case-control study of bladder cancer and chlorination by-products in treated water (ontario, canada). Cancer Causes \& Control 7 (6), 596 - 604.
Marsh, H. \& Wynne-Jones, W. F. (1964) The surface properties of carbon-i the effect of activated diffusion in the determination of surface area. Carbon 1 (3), $269-279$.

Oкоya, A. A., Akinyele, A. B., Amuda, O. S., \& Ofoezie, I. E. (2016) Chitosan-Grafted Carbon for the sequestration of heavy metals in aqueous solution. American Chemical Science Journal 11 (3), 1 - 14. ISSN: 2249-0205, 2016.

Onundi, Y. B., Mamun, A., Al Khatib, M., Al SaAdi, M. \& Suleyman, A. (2011) Heavy metals removal from synthetic wastewater by a novel nano-size composite adsorbent. International Journal of Environmental Science \& Technology 8 (4), $799-806$.

Peng, X., Li, Y., Luan, Z., Di, Z., Wang, H., Tian, B. \& JIA, Z. (2003) Adsorption of 1, 2-dichlorobenzene from water to carbon nanotubes. Chemical physics letters $376(1-2), 154-158$.

Richardson, S. D., Plewa, M. J., Wagner, E. D., Schoeny, R. \& Demarini, D. M. (2007) Occurrence, genotoxicity, and carcinogenicity of regulated and emerging disinfection by-products in drinking water: A review and roadmap for research. Mutation Research/Reviews in Mutation Research 636 (1-3), 178 - 242.

Salman, J. M. \& Hameed, B. H. (2011) Removal of Insecticide Carbofuran fromAqueous Solution by Banana Stalks Activated Carbon. Journal of Hazardous Materials 176 (1 - 3), $814-819$.

Shaibu-Imodagbe, E., Charles, A., John, P. \& AkPAN, B. (2015) Determination of Levels of Regulated and Emerging Trichloromethanes (TCM) Disinfection By-Products (DBPs) in a Community Drinking Water Supply. Journal of Environment and Earth Science 5 (6), $32-39$.

Staroń, P., Chwastowski, J. \& Banach, M. (2017). Sorption and desorption studies on silver ions from aqueous solution by coconut fiber. Journal of Cleaner Production 149, 290 - 301. 
Susheela, P. \& Radha, R. (2015) Production of Activated Carbon From Dry Coconut Shell And Its Efficacy In Treating Waste Water. International Journal of Clinical and Biological Sciences Research Paper 1 (10), 1 - 9.

Tan, I. A. W., Ahmad, A. L. \& Hameed, B. H. (2008) Adsorption of Basic Dye on High-Surface-Area Activated Carbon Prepared from Coconut Husk: Equilibrium, Kinetic and Thermodynamic Studies. Journal of Hazardous Materials $154(1-3), 337$.

Villanueva, C. M., Cantor, K. P., Cordier, S., JaAKkola, J. J., King, W. D., Lynch, C. F., Porru, S. \& Kogevinas, M. (2004) Disinfection byproducts and bladder cancer: A pooled analysis. Epidemiology, $357-367$.

Villanueva, C. M., Cordier, S., Font-Ribera, L., Salas, L. A. \& Levallois, P. (2015) Overview of disinfection by-products and associated health effects. Current environmental health reports 2 (1), $107-115$.
Villanueva, C. M., Fernandez, F., Malats, N., Grimalt, J. O. \& Kogevinas, M. (2003) Meta-analysis of studies on individual consumption of chlorinated drinking water and bladder cancer. Journal of Epidemiology \& Community Health 57 (3), 166 - 173.

Wang, S. \& Wu, H. (2006) Environmental-benign utilisation of fly ash as low-cost adsorbents. Journal of Hazardous Materials 136 (3), 482 -501 .

YANG, T. \& LuA, A. (2003) Characteristics of activated carbons prepared from pistachionut shells by physical activation. Journal of Colloid and Interface Science 267, 408 - 417.

Yerima, I. \& Grema, M. Z. (2018) The potential of coconut shell as biofuel. Journal of Middle East North African Science 4 (8), 11 - 15.

Received 16 Oct 19; revised 27 Mar 20. 